\title{
DZIAŁ MAJĄTKU SUBDELEGATA GRODZKIEGO RADOMSKIEGO STANISŁAWA RAKOWSKIEGO Z 1786 ROKU
}

\author{
Mariusz Kozdrach (D) http://orcid.org/0000-0003-2265-6820 \\ Radomskie Towarzystwo Naukowe
}

\begin{abstract}
THE 1786 ESTATE SETTLEMENT OF STANISŁAW RAKOWSKI, A CASTLE COURT OFFICIAL OF RADOM
\end{abstract}

Stanisław Rakowski (d. post-1786), was one of the many anonymous representatives of the Polish judicature of the 18th c. Politically uninvolved, he spent a few decades in Radom, where he worked and lived as a member of the town's elite (he never owned any land). In 1785 he transmitted his several-thousand property, gathered over the years, to his children: a son (rev. Ignacy) and two daughters (married to noblemen from lawyers families). The document, being an effect of the agreement between Rakowski's successors, is the object of the present study. The estate settlement, preserved in the 19th-century mortgage book, belongs to the sparse descriptive sources on the pre-partition Radom and the material culture of its elite, as the basic sources on the Old-Polish Sandomierz Voivodeship had been destroyed during WWII. Above all, the act is a valuable relic of the Old-Polish law, presenting the manner of dividing property among the landless nobility (impossessionati): a problem slightly examined in Polish historiography.

Keywords: nobility, Radom, property division, castle court office, sources, 18th c.

Słowa kluczowe: szlachta, Radom, podział majątku, urząd grodzki, źródła, XVIII wiek.

Szlacheckie podziały majątkowe cieszą się zdecydowanie mniejszym zainteresowaniem historyków niż testamenty czy inwentarze ruchomości. Wprawdzie w 2013 roku spod pióra Jacka Pielasa wyszła monografia dotycząca aktów divisionis bonorum terrestrium szlachty koronnej w XVII wieku ${ }^{1}$, nie wpłynęło to jednak

${ }^{1}$ J. Pielas, Podziały majątkowe szlachty koronnej w XVII wieku, Kielce 2013 (tu przegląd literatury przedmiotu).

Adres do korespondencji: kozdrachmariusz@wp.pl 
na wzrost zainteresowania tą grupą źródeł. Widać to zwłaszcza na polu edytorskim, gdzie - w przeciwieństwie do testamentów staropolskich ${ }^{2}$ - jedyną pozycją książkową pozostaje, wydana na marginesie wspomnianej monografii, edycja 30 siedemnastowiecznych dokumentów z obszaru województwa sandomierskiego ${ }^{3}$.

Prezentowany niżej akt działu majątku subdelegata grodzkiego radomskiego Stanisława Rakowskiego stanowi przykład dywizji wśród szlachty nieosiadłej - zagadnienia dotąd pomijanego w badaniach ${ }^{4}$. Jest także głosem w kwestii składu elit prowincjonalnych miasteczek u schyłku istnienia Rzeczypospolitej i obecności szlachty w miastach ${ }^{5}$. Niniejsza edycja ma jednocześnie na celu zwrócenie uwagi na potencjał dziewiętnastowiecznych akt hipotecznych w badaniach nad epoką przedrozbiorową, w sytuacji gdy - jak między Wisłą a Pilicą ${ }^{6}$ - nie zachowały się staropolskie księgi ziemskie i grodzkie ${ }^{7}$.

Dostępne źródła niestety nie pozwalają na zbyt szczegółowe przedstawienie sylwetki Stanisława Rakowskiego ${ }^{8}$. Nie ma pewności, skąd się wywodził ${ }^{9}$, ani kiedy

${ }^{2} \mathrm{Z}$ ostatnio wydanych m.in. Testamenty szlachty Prus Królewskich z XVII wieku, oprac. J. Kowalkowski, W. Nowosad, Warszawa 2013; Testamenty szlachty Prus Królewskich z XVIII wieku, oprac. W. Nowosad, J. Kowalkowski, Warszawa 2016; Testamenty szlacheckie z ksiag grodzkich wielkopolskich z lat 1681-1700, oprac. P. K1int, Wrocław 2015; Testamenty chtopów polskich od drugiej połowy XVI do XVIII wieku, oprac. J. Ło o ow ski, Lublin 2016; Testamenty szlacheckie z ksiag grodzkich i ziemskich ziemi halickiej $w$ XVII wieku, oprac. P. Klint, K. Rzemieniecki, J. Węglorz, Wrocław 2018. Wspomnieć można tu również katalogi testamentów mieszczańskich: Katalogi testamentów mieszkańców miast z terenów Korony i Wielkiego Księstwa Litewskiego do 1795 roku, red. U. Augustyniak, t. 1-7, Warszawa 2017.

3 Źródla i materiały do dziejów szlachty województwa sandomierskiego w XVI-XVIII wieku, t. 3: Akty podziałów dóbr ziemskich szlachty sandomierskiej z XVII wieku, oprac. J. Pielas, Kielce 2014.

${ }^{4}$ Por. J. Pielas, Podziaty..., s. 17, 325.

${ }_{5}$ T. Zielińska, Szlacheccy właściciele nieruchomości w miastach XVIII w., Warszawa-Lódź 1987, s. 126-127 i n. Problemowi temu poświęcona była konferencja naukowa zorganizowana przez Zespół Historii Miast przy Komitecie Nauk Historycznych PAN w 2016 r., której rezultaty opublikowano na łamach „Klio. Czasopismo poświęcone dziejom Polski i powszechnym” (Toruń) 2017, t. 42, nr 3.

${ }^{6}$ A. Wolff, Akta partykularne przedrozbiorowe Archiwum Gtównego 1381-1835 [w:] Straty archiwów i bibliotek warszawskich w zakresie rękopiśmiennych źródet historycznych, t. 1: Archiwum Główne Akt Dawnych, Warszawa 1957, s. 195-205.

${ }^{7}$ Wydawcy źródeł z terenu staropolskiego województwa sandomierskiego wśród materiałów wartych objęcia kwerendą nie wymieniają dziewiętnastowiecznych akt sądowo-administracyjnych, por. Źródła i materiały..., t. 3, s. XIII-XV; H. Suchojad, Metodologiczne i praktyczne uwarunkowania edycji testamentów - kilka uwag na kanwie publikacji ,C Cui contingit nasci... ”, „,Kwartalnik Historii Kultury Materialnej” (Warszawa), R. 63, 2015, z. 4, s. 607.

${ }^{8}$ Nawet w sytuacji, gdy dostępny jest komplet ksiąg grodzkich rekonstrukcja biografii urzędników grodzkich sprawia trudności, por. R. Jop, Środowisko urzędnicze kancelarii grodzkich w Chetmie, Lublinie i Krasnymstawie w drugiej polowie XVII wieku, Lublin 2003, passim.

${ }^{9}$ K. Niesiecki, Herbarz Polski, t. 8, wyd. J.N. Bobrowicz, Lipsk 1841, s. 88-90 wymienia kilka rodzin szlacheckich o nazwisku Rakowski, pieczętujących się herbami Kościesza, Lubicz, Radwan i Trzywdar. W drugiej połowie XVIII w. w województwie sandomierskim dziedziczyli ci ostatni (h. Trzywdar). Dobra Mnin (pow. chęciński) należały w 1756 r. do podczaszego wiskiego Wojciecha Rakowskiego (elektora Stanisława Augusta z województwem sandomierskim), w 1783 r. majątek posiadała wdowa po nim, a w pocz. XIX w. Adam Rakowski starosta lubieński i kawaler Orderu Św. Stanisława, jednocześnie arendowny posesor klucza szumskiego na Wołyniu. Ewentualne pokrewieństwo 
i w jakich okolicznościach przybył do Radomia. Miejscowe metryki parafialne potwierdzają jego obecność w mieście co najmniej od marca 1756 roku $^{10}$. Już w sierpniu 1757 roku tytułowany był zaś subdelegatem grodzkim radomskim ${ }^{11}$, co - zważywszy na wymagane na tej funkcji przygotowanie (doświadczenie) prawnicze ${ }^{12}$ - może sugerować, że został ściągnięty przez starostę do pracy w radomskim grodzie. O wykształceniu ani o wcześniejszych etapach kariery Rakowskiego nic nie wiadomo, potwierdzeniem jego wysokich kompetencji jurystycznych i kancelaryjnych jest jednak fakt, że co najmniej od 1769 roku $^{13}$ (być może już w $1763^{14}$ ) do około 1772 roku $^{15}$

subdelegata grodzkiego radomskiego z tą rodziną pozostaje jednak nieustalone, Lvìvska Nacìnalna Naukova Bìblìoteka Ukraïni im. V. Stefanika (dalej: LNNBU), f. 141, op. 2, sp. 606, plenipotencja M. Rakowskiego I. Rakowskiemu, Stara Wieś 23 IX 1783, k. 9; ibidem, kontrakt o Szumsko, Szumsko 24 V 1799, k. 16-17v; ibidem, ustanowienie pełnomocnictwa A. i R. Rakowskich, Żytomierz 12 V 1797, k. 30; , Regestr diecezjów” Franciszka Czaykowskiego, czyli właściciele ziemscy w Koronie w 1783 r., wyd. S. Górzyński, Warszawa 2009, s. 107; Stownik miejscowości i elity wiejskiej zachodniej Małopolski w latach 1772-1815, oprac. Ł. Jewuła, T. Kargol, K. Ślusarek, Kraków 2015 (cz. 1: Miejscowości zachodniej Małopolski), URL: http://www.gospodarka-galicji.pl/slownik-miejscowosci/ (dostęp: 15.05.2019); Elektorów poczet którzy niegdyś głosowali na elektów: Jana Kazimierza r. 1648, Jana III r. 1674, Augusta II r. 1697 i Stanisława Augusta r. 1764, Najjaśniejszych Królów Polskich, Wielkich Ksiażą Litewskich, oprac. O. Pietruski, Lwów 1845, s. 300; J. Wiśniewski, Dekanat konecki, Radom 1913, s. 160; S. Uruski, Rodzina. Herbarz szlachty polskiej, t. 15, oprac. A. Włodarski, Warszawa 1931, s. 162; M. Kobierecki, Walewscy herbu Kolumna w XVII-XVIII wieku. Genealogia. Majętności. Działalność publiczna, Łódź 2008, s. 73. T. Zielińska, op. cit., s. 127 wskazywała przykłady członków palestry podszywających się pod szlachtę, m.in. subdelegata grodzkiego krakowskiego Piotra Maszewskiego, skazanego za to w 1792 r. „,na wieżę".

${ }^{10}$ Księgi Metrykalne Kościołów Radomskich (dalej: KMKR), seria A, t. 9, oprac. D. Kupisz, J. Orzechowski, Radom 2012, s. 74. Według katalogu alumnów tykocińskiego seminarium syn Stanisława Rakowskiego, Ignacy, urodził się w 1754 r. na terenie archidiecezji gnieźnieńskiej, co może wskazywać na datę post quem sprowadzenia się Rakowskich do Radomia, por. J. Łupiński, Seminarium duchowne w Tykocinie w latach 1769-1863, Łódź 2011, s. 327.

${ }^{11}$ Archiwum Państwowe w Radomiu (dalej: APR), Hipoteka miejska miasta Radomia (dalej: HmR), sygn. 441, kontrakt zastawny na dworek w Radomiu F.X. Kietliński J. Kłosińskiemu, Radom 4 VIII 1757, s. 10.

${ }^{12}$ Subdelegat był mianowanym przez starostę urzędnikiem przysięgłym, zobowiązanym do pełnienia czynności procesowych w terenie (kondescensje, tradycje), por. J. Ło sow ski, Kancelaria grodzka chetmska od XV do XVIII wieku. Studium o urzędzie, dokumentacji, jej formach i roli w życiu społeczeństwa staropolskiego, Lublin 2004, s. 103-105.

${ }_{13}$ Pod aktem konfederacji z 31 III 1769 r. podpisał się jako ,subdelegat generalny grodzki radomski, pisarz graniczny sandomierski”, LNNBU, f. 5, op. 1, sp. 1407, Akt konfederacji województwa sandomierskiego, Radom, 31 III 1769, s. 115; Kolęda warszawska na rok 1773, b.m.r., k. F7; A. Sozański, Imienne spisy osób duchownych, świeckich $i$ wojskowych, które w pierwszych ośmiu latach panowania króla Stanisława Poniatowskiego od 1764-1772 r. w rządzie lub przy administracyi Rzeczypospolitej udziat brały, Kraków 1866, tabl. V, nr 1234.

14 „Stanisław Rogawski [sic!] pisarz grodzki radomski” (9 XI 1763 r.), KMKR, seria A, t. 9, s. 128. Zapewne błąd w nazwie urzędu popełniony przez księdza lub wydawców źródła. Pisarzem grodzkim radomskim był w tym czasie (1752-1765) Michał Latalski, por. M. Kozdrach, Urzędnicy grodzcy i personel kancelaryjny radomskiego grodu w latach 1764-1795. Spis, „Studia Mazowieckie” (Pułtusk-Ciechanów), R. 13 (26), 2018, nr 4 (w druku).

${ }^{15}$ W 1774 r. pisarzem granicznym sandomierskim był już Gabriel Popiel, por. Kolęda warszawska na rok 1775 , b.m.r., k. G2. 
był równocześnie pisarzem granicznym sandomierskim ${ }^{16}$. Na stanowisku subdelegata utrzymał się zaś przynajmniej do 1786 roku $^{17}$.

Aktywności politycznej nie przejawiał. W latach 1757-1786 używał tytułu łowczego wiskiego ${ }^{18}$, nie wiadomo jednak, czy legalnie ${ }^{19}$, zwłaszcza że łowczymi w tym czasie byli między innymi Józef Jan Kisielnicki (1767-1775)20 i Synezy Jabłoński $(1775-1790)^{21}$. W elekcji Stanisława Augusta nie uczestniczył. Jego nazwisko nie pojawia się także w laudach sejmiku województwa sandomierskiego. Wprawdzie 31 marca 1769 roku znalazł się wśród sygnujących w Radomiu akt przystąpienia województwa do konfederacji barskiej ${ }^{22}$, całe zgromadzenie obywało się jednak pod naciskiem marszałka łęczyckiego Jana Szczawińskiego ${ }^{23}$. Sam subdelegat w działania konfederatów się nie zaangażował.

W ciągu kilkudziesięciu lat pracy Stanisław Rakowski zgromadził majątek wynoszący 7000 zł, w całości zabezpieczone u okolicznej szlachty ${ }^{24}$. Dóbr ziemskich nabyć nie zdołał ${ }^{25}$ lub nie chciał, żyjąc - jak wielu przedstawicieli stanu uprzywi-

16 Pisarz graniczny był mianowanym przez podkomorzego urzędnikiem przysięgłym, odpowiedzialnym za prowadzenie ksiąg podkomorskich, por. Volumina legum (dalej: VL), t. 3, wyd. J. Ohryzko, Petersburg 1859, s. 334; J. Pielas, Kariery urzędnicze i pozycja społeczno-majątkowa podkomorzych ziemskich w Małopolsce w XVI-XVII wieku na tle porównawczym, „Klio. Czasopismo poświęcone dziejom Polski i powszechnym" (Toruń) 2015, t. 32, s. 34-36.

${ }^{17}$ APR, HmR, sygn. 441, dział majątku Stanisława Rakowskiego, Radom, 26 VII 1786, s. 13.

${ }^{18}$ Ibidem, s. 13; ibidem, kontrakt zastawny na dworek w Radomiu F.X. Kietliński J. Kłosińskiemu, Radom, 4 VIII 1757, s. 10; KMKR, seria A, t. 9, s. 160.

${ }_{19}$ Brak informacji o ewentualnych posiadłościach Stanisława Rakowskiego w województwie mazowieckim w tym czasie.

${ }^{20}$ A. Boniecki, Herbarz Polski, t. 10, Warszawa 1907, s. 90.

${ }^{21}$ Ibidem, t. 8, Warszawa 1905, s. 120. Warto zauważyć, że elekcję Stanisława Augusta podpisały dwie osoby posługujące się tytułem łowczego wiskiego - Karol Dunin i Kazimierz Karwowski, Elektorów poczet..., s. 77, 142. O problemie por. K. Mikulski, Podwójna obsada urzędów ziemskich, urzędy „tytularne”/,,nielegalne” w Rzeczypospolitej w XVII-XVIII w. - kilka uwag wstepnych, „Zapiski Historyczne" (Toruń) 2017, t. 82, z. 2, s. 71-82 (zwł. s. 78-79); W. Urban, Podwójne obsadzanie urzędów w staropolskim województwie lubelskim, „Przegląd Historyczny” (Warszawa) 1986, t. 77, z. 1, s. 61-69 (zw1. s. 65-66).

${ }^{22}$ LNNBU, f. 5, op. 1, sp. 1407, Akt konfederacji województwa sandomierskiego, Radom, 31 III 1769 , s. 115.

${ }^{23}$ D. Kupisz, Konfederaci barscy i Kazimierz Pułaski w regionie radomskim [w:] Kazimierz Pułaski i jego czasy w historii, literaturze, kulturze. W 270 rocznicę urodzin, red. D. Kupisz, A. Pytlak, RadomWarka 2016, s. 11; M. Kozdrach, Radom jako miejsce obrad sejmików i lokalnych zjazdów szlacheckich w drugiej połowie XVIII w., „Przegląd Nauk Historycznych” (Łódź), R. 18, 2019, nr 1 (w druku).

${ }^{24}$ APR, HmR, sygn. 441, dział majątku Stanisława Rakowskiego, Radom, 26 VII 1786, s. 13-15. O możliwościach awansu majątkowego urzędników grodzkich por. m.in. testament subdelegata grodzkiego krakowskiego Kazimierza Antoniego Trębockiego z 1774 r. [w:] Testamenty szlachty krakowskiej XVII-XVIII w. Wybór tekstów źródtowych z lat 1650-1799, oprac. A. Falniowska-Gradowska, Kraków 1997, s. 157-162; T. Zielińska, op. cit., s. 146-147; R. Jop, op. cit., s. 55-56.

${ }^{25}$ Przykłady transakcji kupna-sprzedaży dóbr ziemskich z terenu powiatu radomskiego z połowy lat osiemdziesiątych XVIII w. wskazują, że za majątek ok. jednowioskowy (wyłącznie wsie z poddanymi) trzeba było zapłacić kilkadziesiąt tysięcy złotych, np. Bieniędzice z częściami w Krzyszkowicach i Jarosławicach - 50000 zł w 1781 (APR, Hipteka Powiatowa Radomska [dalej: HPR], sygn. 95, nlb.), Grzmucin - 57000 zł w 1784 r. (ibidem, sygn. 346, s. 114-117), Godów w 1786 - 30000 zł (ibidem, 
lejowanego w miastach $-\mathrm{z}$ odsetek od kapitału ${ }^{26}$. I choć prawo wymagało od osób pełniących w grodzie officia executiva osiadłości w powiecie ${ }^{27}$, jedyną nieruchomością w posesji subdelegata był dworek przy północnej pierzei radomskiego rynku (w sąsiedztwie dworku pisarza grodzkiego radomskiego Michała Latalskiego), wzięty w 1757 roku w zastaw od podczaszyca sandomierskiego Franciszka Ksawerego Odrowąż-Kietlińskiego ${ }^{28}$.

Data śmierci Stanisława Rakowskiego, ani jego losy po 1786 roku nie są znane. Wiadomo, że z małżeństwa z Genowefą Domaszewską ${ }^{29}$ (ślub przed 1754 r.) doczekał się co najmniej trojga dzieci30. Jego jedyny syn, Ignacy (ur. 19 IX 1754 r.), po naukach $\mathrm{w}$ radomskim kolegium pijaró $\mathrm{w}^{31}$ wstąpił do seminarium w Tykocinie, gdzie spędził dwa lata (19 X 1783 r.-28 V 1785 r.) i w 1785 roku otrzymał święcenia kapłańskie ${ }^{32}$. W 1791 roku objął plebanię w Turośni Kościelnej (woj. podlaskie, pow. suraski) z prezenty podkomorzego nurskiego Wiktoryna Zaleskiego ${ }^{33}$. W XIX wieku został archidiakonem białostockim, a zmarł w 1814 roku $^{34}$. Spośród sióstr ks. Ignacego starsza, Izabela ${ }^{35}$ została 22 stycznia 1780 roku wydana za Andrzeja Cieleskiego ${ }^{36}$, rodem z Pomorza, syna ławnika ziemskiego świeckiego Francisz-

sygn. 5774, nlb.), Bryzgów z częściami w Rykowie i Żukówowie - 57000 zł w 1786 (ibidem, sygn. 1301, s. 36-39), Brogowa i Klonowa -80000 zł w 1786 r. (ibidem, Hipoteka Powiatowa Przysuska, sygn. 20, s. 13-14), część Zakrzówka - 55000 zł w 1786 r. (ibidem, Hipoteka Powiatowa Zwoleńska, sygn. 1488, nlb), Jeżowa Wola -48000 zł w 1788 r. (ibidem, HPR, sygn. 5796, k. 3).

${ }^{26}$ T. Zielińska, op. cit., s. 146-147.

27 VL, t. 7, s. 329-330; T. Ostrowski, Prawo cywilne Narodu Polskiego z statutów i konstytucyi koronnych i litewskich zebrane: rezolucyami Rady Nieustaiacey obiaśnione: dodatkami, z praw kanonicznego, magdeburskiego, i chetmińskiego pomnożone: a porzadkiem praw rzymskich ułożone, t. 1 , Warszawa 1787, s. 23-24.

${ }^{28}$ APR, HmR, sygn. 441, kontrakt zastawny na dworek w Radomiu F.X. Kietliński J. Kłosińskiemu, Radom, 4 VIII 1757, s. 10-11. Należy pamiętać, że dla palestry miasto było naturalnym środowiskiem pracy i zamieszkania, por. T. Zielińska, op. cit., s. 126-127.

${ }^{29}$ Być może z Domaszewskich h. Jastrzębiec, z których Antoni - regent (1726), pisarz (1730), wreszcie podstarosci i sędzia grodzki radomski (1730-1735). A. Boniecki, op. cit., t. 4, Warszawa 1901, s. 371; D. Kupisz, Urzędnicy grodzcy radomscy w XVI-XVIII wieku. Stan badań i postulaty badawcze, „Biuletyn Kwartalny Radomskiego Towarzystwa Naukowego” (Radom) 2006, t. 40, z. 1-4, s. 23-24.

${ }^{30}$ Jego córką mogła być też Elżbieta Rakowska, odnotowana jako panna w metrykach radomskiej parafii św. Jana Chrzciciela 6 IX 1770 r., KMKR, seria A, t. 9, s. 174.

${ }^{31} \mathrm{~W}$ katalogu alumnów tykocińskiego seminarium odnotowano jedynie, że kształcił się w Radomiu. W XVIII w. w mieście nie funkcjonowała już jednak szkoła parafialna, a jej funkcję przejęło kolegium pijarów, por. J. Łupiński, op. cit., s. 327; D. Kupisz, Dzieje parafii św. Jana Chrzciciela w Radomiu w XIV-XVIII wieku [w:] Kościót św. Jana Chrzciciela w Radomiu. Architektura. Ludzie. Wydarzenia, red. D. Kupisz, Radom 2010, s. 49.

32 J. Łupiński, op. cit., s. 327.

${ }^{33}$ W. Wróbel, Opieka patronacka rodu Zaleskich h. Chomąto nad kościołem parafialnym w Turośni w XVIII w. [w:] Parafia w Turośni Kościelnej 1515-2015. Ku chwale Trójcy Przenajświętszej, red. A. Szot, M. Wróbel, Białystok-Turośń Kościelna 2015, s. 67.

${ }^{34}$ Ibidem, s. 67-68.

${ }^{35} \mathrm{O}$ starszeństwie sióstr informuje akt podziału dóbr Stanisława Rakowskiego, APR, HmR, sygn. 441, dział majątku Stanisława Rakowskiego, Radom, 26 VII 1786, s. 15.

${ }^{36}$ Ibidem, sygn. 438, wpis do księgi wieczystej nieruchomości Radom ul. Rynek nr hip. 7, s. 15. 
ka Cieleskiego ${ }^{37}$. Zmarła około 1784 roku $^{38}$. Młodsza subdelegacianka, Genowefa, 15 listopada 1785 roku poślubiła burgrabiego nurskiego Józefa Kłosińskiego ${ }^{39}$. Żyła jeszcze w 1843 roku $^{40}$. Obie, jak świadczą metryki chrztów ich dzieci, zamieszkiwały z mężami w Radomiu ${ }^{41}$.

Przeprowadzenie działu majątku Stanisława Rakowskiego wiązać można z zamążpójściem jego najmłodszej córki (kwestie posagowe) ${ }^{42}$, bezpośrednio po ślubie Izabeli subdelegat ustąpił bowiem na rzecz dzieci z praw do posiadanego kapitału i dożywocia na substancji po zmarłej żonie (24 XI 1785 r. $)^{43}$. Nie bez znaczenia dla sprawy był też zapewne fakt, że w ciągu roku poprzedzającego decyzję zmarła starsza subdelegacianka (po 18 X 1784 r.), a owdowiały Andrzej Cieleski - ojciec i prawny opiekun ich córki - ożenił się powtórnie (19 II 1785 r.) $)^{44}$, zaś Ignacy Rakowski ukończył seminarium (28 V 1785 r.) i został księdzem, chyba bez zagwarantowanego beneficjum ${ }^{45}$. Wszyscy oni wywierali zapewne presję na subdelegata. Między pretendentami do majątku doszło zresztą do konfliktu na tle podziału spuścizny, na co wskazuje treść aktu działowego oraz fakt, że jego sporządzenie zajęło aż osiem miesięcy (24 XI 1785 r.-26 VII 1786 r.).

Powstały w wyniku ugody między pretendentami do spuścizny Stanisława Rakowskiego dokument, będący przedmiotem niniejszej edycji, spisano w Radomiu 26 lipca 1786 roku, a 5 dni później (31 VII 1786 r.) oblatowano w księgach grodzkich

${ }^{37}$ M. Bar, Der Adel und der adlige Grundbesitz in Polnisch-Preussen zur Zeit der preussichen Besitzergreifung, Leipzig 1911, s. 13, 23, 113; A. Boniecki, op. cit., t. 3, Warszawa 1900, s. 187; S. Uruski, op. cit., t. 2, Warszawa 1905, s. 310; Urzędnicy Prus Królewskich XV-XVIII wieku. Spisy, oprac. K. Mikulski, Wrocław-Warszawa-Kraków 1990, s. 155; B. Drzewiecki, Szlachta województwa chetmińskiego w latach 1454-1772, Warszawa 2014, s. 188.

${ }^{38}$ Andrzej Cieleski już 19 II 1785 r. ożenił się powtórnie, z córką miecznika radomskiego Franciszka Korwin-Kochanowskiego, Izabelą, KMKR, seria B, t. 4, s. 147 (w metryce Cieleski wymieniony bez imienia); D. Kupisz, M. Kozdrach, Kochanowscy w XV-XVIII wieku, Warszawa 2018, s. 261-262. O długości okresu wdowieństwa (i jego zależności od kwestii majątkowych) w okresie staropolskim por. C. Kuklo, Demografia Rzeczypospolitej przedrozbiorowej, Warszawa 2009, s. 286-287; W. Czapliński, J. Dług osz, Życie codzienne magnaterii polskiej w XVII wieku, Warszawa 1982, s. 33-34; D. Rolnik, Portret szlachty czasów stanisławowskich, epoki kryzysu, odrodzenia i upadku Rzeczypospolitej w pamiętnikach polskich, Katowice 2009, s. 68-69.

${ }^{39}$ KMKR, seria B, t. 5, s. 145.

${ }^{40}$ APR, HmR, sygn. 438, wpis do księgi wieczystej nieruchomości Radom ul. Rynek nr hip. 7, s. $14,17$.

${ }^{41}$ Por. m.in. KMKR, seria A, t. 10, s. 97, 110, 129, 149, 161, 188.

${ }^{42}$ Por. A. Penkała, Panieńskie ochędóstwo. Kwestie posagowe $i$ wienne w matżeństwach szlachty województwa krakowskiego w czasach saskich, Kraków 2016, s. 193-196, 205-209. Intercyza przedślubna z Józefem Kłosińskim nie jest znana.

${ }_{43}$ APR, HmR, sygn. 441, dział majątku Stanisława Rakowskiego, Radom, 26 VII 1786, s. 13.

${ }^{44}$ Ewentualna śmierć córki pozbawiałaby Cieleskiego praw do majątku Rakowskich (w tym posagu żony), por. T. Ostrowski, op. cit., s. 187, 205-206, 210-211.

${ }_{45}$ Warunkiem otrzymania święceń było uzyskanie titulus ordinationis, czyli de facto wskazania źródła dochodu, dopuszczano jednak święcenia na tytuł patrimonium, a więc majątek własny kandydata lub pensję z majątku cudzego, J. Szczepaniak, Duchowieństwo diecezji krakowskiej w XVIII wieku. Studium prozopograficzne, Kraków 2010, s. 285-287. 
radomskich ${ }^{46}$. Jego jedyną znaną kopią - wobec zniszczenia staropolskich akt sądowych z terenu województwa sandomierskiego - jest ekstrakt przedstawiony w 1843 roku przez Konstantego Kłosińskiego (syna Józefa i Genowefy Rakowskiej) przed regentem kancelarii ziemiańskiej guberni sandomierskiej ${ }^{47}$. Wypis przetrwał w tomie załączników (zał. H) do księgi wieczystej nieruchomości przy ulicy Rynek 15 (numeracja z XIX w.) w Radomiu, obecnie przechowywanej w zasobie Archiwum Państwowego w Radomiu w zespole Hipoteka miejska miasta Radomia, pod sygnaturą 441.

Dokument zawiera elementy charakterystyczne dla formularza aktów divisionis bonorum terrestrium ${ }^{48}$, w kilku punktach odbiega jednak od typowego aktu podziałowego. Podstawowa różnica wynika oczywiście z faktu, że przedmiotem dywizji nie były dobra ziemskie, więc określenie substancji ojczystej i macierzystej ograniczało się do wyliczenia kapitałów. Jak się przy tym okazuje, w działach tego rodzaju również obowiązywała zasada przyznająca synom prawo do $3 / 4$ majątku ojca ${ }^{49}$, choć w omawianym przypadku ks. Ignacy Rakowski zgodził się na równiejsze potraktowanie sióstr. Szczególnie interesującym elementem aktu z 1786 roku jest ustalenie zasad korzystania z dworku Kietlińskich, dzielonego w tym celu na trzy odrębne „mieszkania” (jest to jednocześnie jeden z nielicznych opisów przedrozbiorowej zabudowy mieszkalnej Radomia). Dokument nie wskazuje, kto wyznaczył schedy. Zgodnie z prawem i zwyczajem był to obowiązek najstarszego potomka ${ }^{50}$, ks. Ignacy Rakowski nie był jednak obecny przy akcie, lecz działał przez pełnomocnika. To zresztą także specyfika podziału majątku radomskiego subdelegata, żaden bowiem z głównych aktorów postępowania nie działał sam. Księdza Ignacego Rakowskiego reprezentował szwagier Józef Kłosiński, równocześnie asystent Genowefy Kłosińskiej (jako mąż), z kolei w imieniu małoletniej Józefy Cieleskej występował jej ojciec Andrzej Cieleski. Dość nietypowe jest również zakończenie aktu, zbliżone raczej do „formy komplanacji” znanej z dzieła Teodora Ostrowskiego ${ }^{51}$ niż do typowych formuł końcowych dywizji.

\section{$* * *$}

Przygotowując akt podziału majątku Stanisława Rakowskiego do druku, kierowano się wskazaniami instrukcji wydawniczej dla źródeł nowożytnych ${ }^{52}$, czyniąc jednak - wzorem edycji z ostatnich lat ${ }^{53}$ - pewne odstępstwa od tych reguł na rzecz zwiększenia przejrzystości i czytelności tekstu. Ograniczanie ingerencji językowych,

${ }^{46}$ APR, HmR, sygn. 441, dział majątku Stanisława Rakowskiego, Radom, 26 VII 1786, s. 12, 19.

${ }^{47}$ Ibidem, sygn. 438, wpis do księgi wieczystej nieruchomości Radom ul. Rynek nr hip. 7, s. 12-17.

${ }^{48}$ Por. J. Pielas, Podziaty..., s. 53-82.

${ }^{49}$ Por. ibidem, s. 32-34, 148.

${ }^{50}$ Ibidem, s. 144-145.

51 T. Ostrowski, op. cit., t. 2, s. 319-320.

52 Instrukcja wydawnicza dla źródet historycznych od XVI do połowy XIX w., red. K. Lepszy, Wroclaw 1953.

${ }_{53}$ Zwłaszcza Testamenty chłopów polskich od drugiej połowy XVI do XVIII wieku, oprac. J. Ło sow ski, Lublin 2016, s. LI-LVII. 
stosowane przez część wydawców dla zachowania cech staropolszczyzny i regionalizmów ${ }^{54}$, wydawało się jednak nieuzasadnione w przypadku źródła znanego wyłącznie z dziewiętnastowiecznej kopii ${ }^{55}$.

Treść aktu podano z pominięciem formuł kancelaryjnych (zarówno z XVIII, jak i XIX w.). Strukturę tekstu podzielono na akapity i zmodernizowano interpunkcję, rezygnując przy tym z kropek występujących w źródle po liczbach. Błędy ortograficzne poprawiono bez sygnalizowania. Uwspółcześniono użycie wielkich liter, zachowując je jednak w formach grzecznościowych. Dla tych ostatnich wprowadzono konsekwentny system skrótów (JMP - Jegomość Pan, IMMPP - Ichmoście Państwo, JW - Jaśnie Wielmożny, W - Wielmożny), podobnie jak dla jednostek pieniężnych (zł - złoty, gr - grosz). W zapisach kwot zmieniono szyk (np. „2030 złotych groszy 18 polskich” > „2030 zł 18 gr”). Błędy obliczeniowe (dot. groszy), wobec niemożności rozstrzygnięcia, czy pochodzą z epoki, czy powstały przy kopiowaniu źródła w XIX wieku, pozostawiono bez korekty i bez sygnalizowania. Poprawiono i ujednolicono pisownię nazwisk (np. Kłosieński > Kłosiński, Cielecki/Cielewski > Cieleski). Dopełniaczową formę nazwisk kobiecych uwspółcześniono (np. Pani Rakowski $>$ Pani Rakowskiej). Wyrazy i zwroty łacińskie zapisywano kursywą. Wzorem edycji testamentów chłopskich Janusza Łosowskiego numery stron, podawane w nawiasach kwadratowych, wyróżniono pogrubionym drukiem. W przypisach zamieszczono objaśnienia mniej zrozumiałych wyrazów oraz zwięzłe noty biograficzne osób wymienionych w tekście źródła.

\section{EDYCJA ŹRÓDŁA}

Oryginal: nieznany.

Kopia I (zaginiona): Księgi grodzkie radomskie. Oblaty, Księga z roku 1786 (b. sygn.), k. 398. Do akt 30 lipca 1786 r. wnieśli Józef Kłosiński i Andrzej Cieleski. Kopia II: Archiwum Państwowe w Radomiu, Hipoteka miejska miasta Radomia, sygn. 441, s. 12-19. Ekstrakt z ksiąg grodzkich radomskich sporządzony w 1843 r. na papierze stemplowym (wartości 7,5 kop.), uwierzytelniony pieczęcią urzędową w czerwonym laku i podpisem archiwisty akt dawnych polskich guberni sandomierskiej (Chlewickiego), wszyty do tomu załączników (zał. H) księgi wieczystej nieruchomości przy ul. Rynek 15 w Radomiu (ob. cz. nieruchomości ul. Rynek 1).

54 Testamenty szlachty krakowskiej..., s. XIX-XX; Cui contingit nasci, restat mori. Wybór testamentów staropolskich z województwa sandomierskiego, oprac. M. Lubczyński, J. Pielas, H. Suchojad, Warszawa 2005, s. 12-13

55 Por. Testamenty szlachty Prus Królewskich z XVII..., s. 55. 
[s. 12] Między urodzonemi IMMPP Józefem Kłosińskim¹, imieniem JM księdza Ignacego Rakowskiego ${ }^{2}$, z mocy specyjalnej przed aktami grodzkiemi radomskiemi dnia 18 miesiąca lutego roku bieżącego zapisanej plenipotencyi ${ }^{3}$ czyniącym z jednej, a JMP Jędrzejem Cieleskim ${ }^{4}$, niegdy JMP Izabeli z Rakowskich ${ }^{5}$ pozostałym małżonkiem, imieniem JM Panny Józefy Cieleskiej ${ }^{6}$, córki swojej z pomienioną niegdy JMP Izabelą z Rakowskich małżonką swoją spłodzonej małoletniej ojcem, naturalnym opiekunem czyniącym z drugiej, tudzież JMP Genowefą z Rakowskich Kłosińską,

${ }^{1}$ Józef Kłosiński h. Lubicz (zm. 1826) - palestrant grodzki radomski (1780), burgrabia grodzki nurski (1785), w okresie Księstwa Warszawskiego i Królestwa Polskiego pisarz Sądu Pokoju w Radomiu (1810-po 1824), mąż Genowefy z Rakowskich (por. przyp. 7). Księgi Metrykalne Kościołów Radomskich (dalej: KMKR), seria B, t. 5, s. 145; Kalendarzyk Polityczny Piiarski na rok przestępny 1811, b.m.r., s. 145; Nowy Kalendarzyk Polityczny na rok 1825, Warszawa [1824], s. 158; A. Boniecki, Herbarz Polski, t. 10, Warszawa 1907, s. 184; M. Kozdrach, Urzędnicy grodzcy i personel kancelaryjny radomskiego grodu w latach 1764-1795. Spis, „Studia Mazowieckie” (Pułtusk-Ciechanów), R. 13 (26), 2018, $\mathrm{nr} 4$ (w druku).

${ }^{2}$ Ignacy Rakowski (1754-1814) - syn subdelegata grodzkiego radomskiego Stanisława Rakowskiego (por. przyp. 8), kleryk seminarium w Tykocinie (1783-1785), w 1785 r. wyświęcony na księdza, od 1791 r. pleban w Turośni (woj. podlaskie), w XIX w. archidiakon białostocki (1808-1814). J. Łupiński, Seminarium duchowne w Tykocinie w latach 1769-1863, Łódź 2011, s. 327; W. Wróbe1, Opieka patronacka rodu Zaleskich h. Chomąto nad kościołem parafialnym w Turośni w XVIII w. [w:] Parafia w Turośni Kościelnej 1515-2015, red. A. Szot, M. Wróbe1, Białystok-Turośń Kościelna 2015, s. 67-68.

${ }^{3}$ Por. Archiwum Państwowe w Radomiu (dalej: APR), Hipoteka miejska miasta Radomia (dalej: HmR), sygn. 441, plenipotencja I. Rakowskiego J. Kłosińskiemu, Lublin, 18 II 1786, s. 24.

${ }^{4}$ Andrzej (Jędrzej) Cieleski h. Doliwa (ok. 1754-przed 1824 r.) - syn ławnika ziemskiego świeckiego Franciszka Cieleskiego, dziedzica Gołuszyc (woj. chełmińskie), w 1776 r. dzierżawca sąsiedniego Łowina od Tuchołków, wkrótce zapewne opuścił zabór pruski, mąż Izabeli z Rakowskich (por. przyp. 5), po jej śmierci ożenił się powtórnie z miecznikówną radomską Izabelą z Kochanowskich h. Korwin (małż. 19 II 1785), z której doczekał się m.in. Hipolita Stefana Franciszka (chrz. 13 VIII 1792). APR, Hipoteka Powiatowa Radomska (dalej: HPR), sygn. 2362, wyrok Trybunału Cywilnego I Instancji Województwa Sandomierskiego, Radom, 20 IV 1825, s. 168, 221; KMKR, seria B, t. 4, s. 147; ibidem, seria A, t. 13, s. 116-117; M. Bar, Der Adel und der adlige Grundbesitz in Polnisch-Preussen zur Zeit der preussichen Besitzergreifung, Leipzig 1911, s. 13, 23, 113; A. Boniecki, op. cit., t. 3, Warszawa 1900, s. 187; S. Uruski, Rodzina. Herbarz szlachty polskiej, t. 2, Warszawa 1905, s. 310; Szlachta wylegitymowana w Królestwie Polskim w latach 1836-1861, oprac. E. Sęczys, Warszawa 2007, s. 96; Urzędnicy Prus Królewskich XV-XVIII wieku. Spisy, oprac. K. Mikulski, Wrocław-Warszawa-Kraków 1990, s. 155; D. Kupisz, M. Kozdrach, Kochanowscy w XV-XVIII wieku, Warszawa 2018, s. 262.

${ }^{5}$ Izabela z Rakowskich Cieleska (zm. ok. 1784) - córka subdelegata grodzkiego radomskiego Stanisława Rakowskiego (por. przyp. 8), od 22 I 1780 r. żona Andrzeja Cieleskiego (por. przyp. 4), matka co najmniej trojga dzieci: Dionizego Józefa (chrz. 6 IV 1781, zm. 30 VII 1782), Genowefy Józefy (chrz. 3 I 1783) i Łukasza Piotra Antoniego (chrz. 28 X 1784), z których w 1786 r. żyła już tylko jedna córka (por. przyp. 6), KMKR, seria B, t. 5, s. 132; ibidem, seria A, t. 10, s. 97, 110, 129, ibidem, seria C, t. 1, s. 102.

${ }_{6}^{6}$ Józefa Cieleska (ok. 1782-po 1843) - córka Andrzeja Cieleskiego (por. przyp. 4) i Izabeli z Rakowskich (por. przyp. 5), prawdopodobnie tożsama z Genowefą Józefą chrzczoną 3 I 1783 r. w Radomiu, jako jedyna z rodzeństwa żyła jeszcze w 1786 r., po 1837 r. zamężna Rousseau? („Roussowa”), APR, HmR, sygn. 438, wpis do księgi wieczystej nieruchomości Radom ul. Rynek nr hip. 7, s. 14, 17; KMKR, seria A, t. 10, s. 110.

${ }^{7}$ Genowefa z Rakowskich Kłosińska (zm. po 1843) - córka subdelegata grodzkiego radomskiego Stanisława Rakowskiego (por. przyp. 8), od 15 XI 1785 r. żona burgrabiego nurskiego Józefa Kłosińskiego (por. przyp. 1), matka co najmniej czworga dzieci: NN córki (chrz. 5 XII 1786), Witala Stanisława Tadeusza (chrz. 29 IV 1788), Konstantego (chrz. 25 VII 1789) i Benedykty Julianny (chrz. 26 III 1791), 
w asystencyi JMP Józefa Kłosińskiego męża swego czyniącą z trzeciej strony stawa takowy substancyi ojczystej i macierzystej dział i w niczym [s. 13] nieodmienne postanowienie.

A najprzód, po uczynionych przed aktami grodzkiemi radomskiemi przez WJMP Stanisława Rakowskiego ${ }^{8}$, łowczego wiskiego i subdelegata grodzkiego radomskiego, ojca, na dniu 24 listopada roku zeszłego 1785 od dożywocia substancyi niegdy WJP Genowefy z Domaszewskich ${ }^{9}$ małżonki swojej i oddania w podział tejże substancyi, jako też i swojej własnej ${ }^{10}$, niniejszym komplanującym się dzieciom nastąpić mianej, tudzież przez JMP Jędrzeja Cieleskiego [na] dniu 29 kwietnia r[oku] bieżącego od cesyi dwóch sum u W Adama Tymińskiego ${ }^{11}$, wicesgerenta grodzkiego radomskiego zaległych, przez tegoż JMP Stanisława Rakowskiego, ojca, na osobę jego zeznanej autentycznych recesach ${ }^{12}$, że dobrowolna takowa między stronami nastąpiła ugoda, aby $\mathrm{i}$ te transakcyje na rzecz recesujących się służące do u[ro]bienia prawnie należytego działu nie przeszkadzały, do ustanowienia masy całkowitej substancyi macierzystej i ojczystej przez wyrażenie każdej w szczególności sumy udziałać mianej przystępują.

Sumy kapitalnej niegdy JMP Genowefy z Domaszewskich Rakowskiej własnej 2030 zł 18 gr, przez JW Michała Świdzińskiego ${ }^{13}$, kasztelana radomskiego, zapisem

z których dwoje starszych zmarło na przełomie 1789 i 1790 r., APR, HmR, sygn. 438, wpis do księgi wieczystej nieruchomości Radom ul. Rynek nr hip. 7, s. 12-13, 15, 18; KMKR, seria B, t. 5, s. 145, ibidem, seria A, t. 10, s. 149, 161, 173, 188, ibidem, seria C, t. 1, s. 144.

${ }^{8}$ Stanisław Rakowski (zm. po 1786) - rzekomy łowczy wiski (1757-1786), subdelegat grodzki radomski (1757-1786), rzekomy burgrabia radomski (1761), pisarz graniczny sandomierski (1769-1772), zastawny posesor dworku Kietlińskich położonego w radomskim rynku, mąż Genowefy z Domaszewskich (por. przyp. 9), ojciec ks. Ignacego Rakowskiego (por. przyp. 2), Izabeli Cieleskiej (por. przyp. 5) i Genowefy Kłosińskiej (por. przyp. 7), APR, HmR, sygn. 441, kontrakt zastawny na dworek w Radomiu F.X. Kietliński J. Kłosińskiemu, Radom, 4 VIII 1757, s. 10; ibidem, dział majątku Stanisława Rakowskiego, Radom, 26 VII 1786, s. 12 i n.; ibidem, dekret sądu kompromisarskiego na gruncie dóbr Milejowice, 13 IV 1761, s. 20-21; Lvìvska Nacìonalna Naukova Bìblìoteka Ukraïni im. V. Stefanika (dalej: LNNBU), f. 5, dz. I, sp. 1407, Akt konfederacji województwa sandomierskiego, Radom, 31 III 1769, s. 115; Kolęda warszawska na rok 1773, b.m.r., k. F7; A. Sozański, Imienne spisy osób duchownych, świeckich $i$ wojskowych, które w pierwszych ośmiu latach panowania króla Stanisława Poniatowskiego od 17641772 r. w rządzie lub przy administracyi Rzeczypospolitej udział brały, Kraków 1866, tabl. V, nr 1234.

${ }^{9}$ Genowefa z Domaszewskich Rakowska (zm. przed 1785) - żona subdelegata grodzkiego radomskiego Stanisława Rakowskiego (por. przyp. 8). Postać bliżej nieznana.

${ }^{10}$ Dokument nieznany.

${ }^{11}$ Adam Tymiński h. Nałęcz (zm. po 1801) - syn stolnika sandomierskiego i podstarościego stężyckiego Antoniego Tymińskiego, wicesgerent grodzki radomski (1764-1792), dziedzic części Tynicy i Zakrzówka (pow. radomski). APR, Hipoteka Powiatowa Zwoleńska, sygn. 1488, kontrakt kupna-sprzedaży dóbr Zakrzówek, Zakrzówek, 6 IX 1786, nlb.

12 Dokument nieznany.

${ }^{13}$ Michał Świdziński h. Półkozic (1736-1788) - syn wojewody rawskiego Stanisława Antoniego Świdzińskiego, starosta radomski (1757-1772), kasztelan radomski (1772-1788), dziedzic klucza sulgostowskiego obejmującego m.in. miasteczko Klwów (pow. radomski). U. Kosińska, Świdziński Michat h. Pótkozic (1736-1788) [w:] Polski stownik biograficzny, t. 51, Warszawa-Kraków 2017, s. 289-292;

D. Kupisz, Czasy Rzeczypospolitej szlacheckiej (XVI-XVIII wiek) [w:] D. Kupisz, Z. Lechowicz, S. Piątkowski, Dzieje Klwowa i parafii klwowskiej do roku 1918, Radom 2015, s. 81; Urzędnicy województwa sandomierskiego XVI-XVIII wieku. Spisy, oprac. K. Chłapowski, A. Falniowska-Gradowska, Kórnik 1993, s. 72, 80-81. 
w aktach grodzkich radomskich dnia 25 sierpnia r[oku] 1777 zabezpieczonej ${ }^{14}$. Tymże samym dniu i roku tego własnej [sumy] JMP Stanisława Rakowskiego u [s. 14] pomienionego JW kasztelana z całkowitej 2969 zł 12 gr reszty sumy 969 [zł] 12 gr zapisem stwierdzonej został ${ }^{15}$. U W Adama Tymińskiego, wicesgerenta grodzkiego radomskiego, dekretem grodzkiem radomskim dnia 10 lutego roku 1784 zapadłym ${ }^{16}$, sum dwóch, wraz z luitą ${ }^{17}$ przy tym dekrecie przyłączoną, 700 zł wynoszących, na rzecz tegoż W Stanisława Rakowskiego, ojca, przysądzonych. U JMP Jędrzeja Cieleskiego od JW kasztelana radomskiego, in vim posagu niegdy JMP Izabeli z Rakowskich, małżonce jego, należącego, z wyżej wymienionej sumy całkowitej 2969 zł 12 gr ojczystej sumy kapitalnej 1000 zł odebranej, a zapisem przez niego w aktach grodzkich radomskich dnia 6 lipca roku 1782 zeznanym $^{18}$, na rzecz niegdy JMP Izabeli z Rakowskich, małżonki, i sukcesorki z nią spłodzonej, zabezpieczony zostaje. Na dworku w mieście Radomiu sytuowanym, WW Kietlińskich ${ }^{19}$ dziedzicznym, sumy 2300 zł kontraktem zastawnym przez niegdy W Kietlińskiego, podczaszego sandomierskiego ${ }^{20}$, JMP Stanisławowi Rakowskiemu należącej, na dniu 24 sierpnia roku 1757 zaasekurowanej ${ }^{21}$, a potym dekretami kilkoma zatwierdzonej ${ }^{22}$ zostaje. $^{2}$ Które to kapitały wyszczególnione, gdy ogółem [s. 15] całkowitej substancyi macierzystej i ojczystej masę in summa 7000 zł czynią, więc takowym majątkiem jak najsłuszniej i najproporcyjonalniej strony komplanujące się dzielić deklarują.

W porządku którego wydzielenia, ponieważ JM ksiądz Ignacy Rakowski, brat, przez JMP Józefa Kłosińskiego plenipotenta swego czyniący, tylko z jednej sumy, to jest 969 zł 12 gr u JW kasztelana, jako wyżej wspomniano będącej ojczystej, trzy części

${ }^{14}$ Dokument nieznany.

${ }^{15}$ Dokument nieznany.

${ }_{16}$ Dokument nieznany.

${ }^{17}$ Luita - łac. suma pieniężna.

${ }^{18}$ Dokument nieznany.

${ }_{19}$ Dworek Kietlińskich - nieruchomość położona w północnej pierzei radomskiego rynku (w poł. XIX w. na miejscu tej oraz sąsiednich działek wzniesiono nowy ratusz miejski - ob. nieruchomość ul. Rynek 1), między domem mieszczan Sadalskich (od zachodu), a dworkiem pisarza grodzkiego radomskiego Michała Latalskiego (od wschodu). W 1797 r. dworek Kietlińskich, wówczas już zadłużony i zrujnowany, nabył na publicznej licytacji - przez podstawionego kupca, niejakiego Mikołaja Osuchowskiego Józef Kłosiński (por. przyp. 1) za kwotę 1820 zł. APR, HmR, sygn. 441, kontrakt między magistratem Radomia a J. Kłosińskim o kupno nieruchomości, Radom, 12 VII 1797, s.1-2; ibidem, akt nabycia nieruchomości na publicznej licytacji przez M. Osuchowskiego, Radom, 3 VII 1797, s. 29-30; ibidem, rezygnacja nieruchomości przez M. Osuchowskiego na rzecz J. Kłosińskiego, Radom, 6 VII 1797, s. 31. W. Kalinowski, Zabudowa rynku radomskiego na przełomie XVIII i XIX wieku, „Biuletyn Kwartalny Radomskiego Towarzystwa Naukowego" 1969, t. 6, z. 4, s. 54.

${ }^{20}$ Józef Kietliński h. Odrowąż (zm. ok. 1756) - syn chorążego parnawskiego Walentego Odrowąż-Kietlińskiego, wojski stężycki (1737-1744), podczaszy sandomierski (1744-1756), podstarości radomski (1742-1753), dziedzic Rawicy i Rdzuchowa (pow. radomski). A. Boniecki, op. cit., t. 10, s. 62; Urzędnicy województwa sandomierskiego..., s. 103; D. Kupisz, Czasy Rzeczypospolitej szlacheckiej (XVI-XVIII wiek) [w:] Powiat radomski. Od średniowiecza do wspótczesności, red. S. Piątkowski, Radom 2009, s. 42.

${ }^{21}$ Por. APR, HmR, sygn. 441, kontrakt zastawny na dworek w Radomiu F.X. Kietliński J. Kłosińskiemu, Radom, 4 VIII 1757, s. 10-11.

${ }^{22}$ Por. ibidem, dekret sądu kompromisarskiego na gruncie dóbr Milejowice, 13 IV 1761, s. 20-23. 
biorąc, a czwartą na siostry zostawując, z innych zaś sum ojczystych do równego działu siostry przypuścić i szanując afekt rodzeństwa tym nieodmiennie kontentować się oświadcza, przeto z ogólnej sumy należy JM księdzu Ignacemu Rakowskiemu 2737 zł 15 gr porcyja. Względem zaś tegoż JM księdza Ignacego Rakowskiego, gdy JM Panna Józefa Cieleska, niegdy JMP Izabeli z Rakowskich z JMP Jędrzejem Cieleskim, na teraz imieniem jej czyniącym, spłodzona, po starszej siostrze córka, oraz i JMP Genowefa z Rakowskich Kłosińska, młodsza siostra, dwie głowy kobiece reprezentują, każdej więc porcyja 2131 zł $7 \frac{1}{2}$ gr przypadająca niniejszą ugodą i przyjacielskim umiarkowaniem ustanawia się, które tym sposobem aplikowane zostaną.

Schedzie pierwszej JM księdza Ignacego Rakowskiego dostaje się z sumy ojczystej 969 zł 12 gr u JW Świdzińskiego, kasztelana radomskiego będącej, suma [s. 16] 727 zł 9 1 12 gr. U W Adama Tymińskiego suma całkowita 700 zł [ ${ }^{a}$ ]. Item na dworku w mieście Radomiu sytuowanym, z całkowitej sumy 2300 zł prawem zastawnym u WW Kietlińskich będącej, dostaje się suma 523 zł 4 gr, z macierzystej zaś całkowitej 2030 zł 18 gr, u wzwyż pomienionego kasztelana radomskiego będącej, dostaje się suma 787 zł $1 \frac{1}{2}$ gr. Wynosi całkowita porcyja tej schedy in summa 2737 zł 13 gr.

Schedzie drugiej JM Panny Cieleskiej dostaje się z sumy ojczystej 969 zł 12 gr u JW Świdzińskiego, kasztelana radomskiego będącej, suma 121 zł 1 1 1/2 gr. Item na dworku w mieście Radomiu sytuowanym, z całkowitej sumy 2300 zł prawem zastawnym u WW Kietlińskich będącej, dostaje się suma 766 zł 20 gr. Item suma całkowita u JMP Jędrzeja Cieleskiego 1000 zł, będąca zapisem przez niego, jako niegdy wyżej wymieniono, ubezpieczona. Z macierzystej zaś całkowitej 2030 zł 18 gr, u wzwyż pomienionego JW kasztelana radomskiego będącej, dostaje się suma $243 \mathrm{zl}$ 16 gr. Wynosi ogólna tej schedy porcyja in summa 2131 zł 7 1⁄2 gr.

Schedzie trzeciej JMP Genowefie Kłosińskiej dostaje się z sumy ojczystej 969 zł 12 gr u JW Świdzińskiego, kasztelana radomskiego będącej, sumy 121 zł 1 11/2 gr. Item na dworku w mieście Radomiu sytuowanym, z całkowitej sumy 2300 zł prawem zastawnym u WW Kietlińskich będącej, dostaje się suma 1010 zł. Z macierzystej zaś całkowitej 2030 zł 18 gr, u wzwyż JW pomienionego kasztelana radomskiego będącej, dostaje się suma 1000 zł. Wynosi ogółem tej schedy porcyja in summa 2131 zł 7 1⁄2 gr.

Po którym uczynionym porcyi należytych wydziale, ponieważ suma [s. 17] $2300 \mathrm{zł}$ prawem zastawy na dworek jest importowana, a z tej sumy każdej stronie biorąc porcyją przyzwoity procent lub tejże zastawy użytek słusznie należeć powinien, przeto strony wyżej wzmiankowane komplanujące się mieszkaniem w tymże dworku w proporcyi sumy, tak aby użytek pomieszkania lub prowent każdemu corocznie służący mógł kapitałowi korespondować, wydzielić się umyśliły. Naprzód w sumie 523 zł 4 gr JM księdzu Ignacemu Rakowskiemu dostaje się izdebka z komorą, kominem, piecem i kuchnią w tyle dworku przy stajni będąca. W sumie 766 zł 20 gr JM Pannie Józefie Cieleskiej dostaje się pomieszkanie po lewej ręce wchodząc z miasta do dworku, w którym pomieszkaniu są dwie izby duże z alkowami, kominami, piecami, oknami i kuchnią. JMP Genowefie Kłosińskiej dostaje się po prawej ręce dworku pomieszkanie, w którym izby dwie z alkowami, dwoma kominami, piecami, oknami i kuchnią,

a Powtórzone: całkowita. 
do tego stajnia cała, na której zrobione pomieszkanie, a to w sumie 1010 zł. Z których jako każdy mieć własną wygodę lub pewny użytek, tak niemniej i reperować lub też przynajmniej aby dezelacyi nie było, starać się powinien. Jeśliby zaś WW Kietlińscy wykupować kiedy z tego dworku oświadczyli się, tedy każdy swoją porcyją wolną do rąk, ewikcyjonalną zaś za bezpiecznym podnieść ma ulokowaniem, a inwentarz całego dworku wraz z kontraktem [s. 18] opisany, jako dawniej w posesyi JMP Cieleskiego przez JMP Stanisława Rakowskiego ojca wypuszczony zostawał, tak tenże JMP Cieleski dworek cały z inwentarzem dziedzicom przy wykupnie oddawać będzie powinien. Do którego dokumenta służące przy tymże JMP Cieleskim zostawać mają.

$\mathrm{Z}$ majątku zaś ponieważ nic znaczniejszego nad cyny funtów ${ }^{23} 21$ (z której każdy bierze po funtów 7) nie znajduje się, przeto innemi statkami ${ }^{24}$ drewnianemi, przyzwoicie na trzy części wydzieliwszy się, też osobnym regestrem ${ }^{25}$ specyfikować strony między sobą postanowiły. Co się zaś tyczy innych, nie windykowanych, tak ojczystych jako i macierzystych lub też spadkowych sum kapitalnych i prowizyjonalnych, gdziekolwiek i jakimkolwiek prawem z sybstancyi wszelakiej ruchomej i nieruchomej, które by niniejszym komplanującym się służyć miały znajdujących się, te jako do teraźniejszego nie wchodzą działu, tak na potym jeżeliby się jakie okazały być, tedy windykować wspólnie i dzielić się niemi razem przy zachowaniu zwyczajnej proporcyi wszyscy powinni będą.

Inne zaś wszelkie z okoliczności działu wypływające pretensyje nawzajem ku sobie miane, jakie tylko być dotąd mogły, niniejszą przyjacielską ugodą odtąd ich nie formować, ani do siebie wznawiać oświadczają. Owszem, pomnażając afekt rodzeństwa z jednomyślnej [s. 19] przychylności one ku sobie wzajemnie miane umarzają.

Co wszystko strony komplanujące wstrzymać pod karami prawem roku 1768 o dobrowolnych transakcyjach ${ }^{26}$ ustanowionemi obowiązują się, a w przypadku któregokolwiek punktu niedotrzymania forum do odpowiedzi grodu lub ziemstwa radomskiego sobie i sukcesorom swoim naznaczając i tę komplanacyją działową natychmiast rękami własnemi w przytomności uproszonych przyjaciół podpisują.

Datum w Radomiu dnia 26 miesiąca lipca roku 1786.

Józef Kłosiński na mocy plenipotencyi od księdza Ignacego Rakowskiego mianej tę komplanacyją podpisuję.

Jędrzej Cieleski imieniem córki mojej Józefy małoletniej podpisuję tę działową komplanacyją.

Genowefa z Rakowskich Kłosińska tę działową komplanacyją podpisuję

Józef Kłosiński do tej komplanacyi asystent.

Proszony do urobienia tego działu przyjaciel podpisuję się Łukasz z Sugczyna [!] Swederski ${ }^{27} \mathrm{mpp}$.

${ }^{23}$ Funt (,warszawski”) - 406,679 g.

${ }^{24}$ Statki - tu: naczynia.

${ }^{25}$ Dokument nieznany.

26 Volumina Legum, t. 7, wyd. J. Ohryzko, Petersburg, 1860, s. 330-331.

${ }^{27}$ Łukasz Swederski (Swęderski, Swenderski) - postać nierozpoznana. Swenderskich h. Półkozic wzmiankuje K. Niesiecki, Herbarz Polski, t. 8, wyd. J.N. Bobrowicz, Lipsk 1841, s. 571. 


\section{BIBLIOGRAFIA}

\section{Źródła rękopiśmienne}

Archiwum Państwowe w Radomiu

Hipoteka miejska miasta Radomia, sygn. 438, 441.

Hipoteka Powiatowa Radomska, sygn. 95, 346, 1301, 5774, 5796.

Hipoteka Powiatowa Przysuska, sygn. 20.

Hipoteka Powiatowa Zwoleńska, sygn. 1488.

Lvìvska Nacìnalna Naukova Bìblìoteka Ukraïni im. V. Stefanika

f. 5 , op. 1 , sp. 1407.

f. 141, op. 2, sp. 606 .

\section{Źródła drukowane}

Cui contingit nasci, restat mori. Wybór testamentów staropolskich z województwa sandomierskiego, oprac. M. Lubczyński, J. Pielas, H. Suchojad, Warszawa 2005.

Elektorów poczet którzy niegdyś głosowali na elektów: Jana Kazimierza r. 1648, Jana III r. 1674, Augusta II r. 1697 i Stanisława Augusta r. 1764, Najjaśniejszych Królów Polskich, Wielkich Książą Litewskich, oprac. O. Pietruski, Lwów 1845.

Kalendarzyk Polityczny Piiarski na rok przestępny 1811, b.m.d.

Kolęda warszawska na rok 1773 , b.m.d.

Kolęda warszawska na rok 1775, b.m.d.

Księgi Metrykalne Kościołów Radomskich, seria A: Metryki chrztów, t. 9: Kościót św. Jana Chrzciciela 1746-1771, oprac. D. Kupisz, J. Orzechowski, Radom 2012.

Księgi Metrykalne Kościołów Radomskich, seria A: Metryki chrztów, t. 10: Kościót św. Jana Chrzciciela 1772-1795, oprac. D. Kupisz, Radom 2012.

Księgi Metrykalne Kościołów Radomskich, seria A: Metryki chrztów, t. 13: Kościół św. Wactawa 1784-1795, oprac. D. Kupisz, Radom 2014.

Księgi Metrykalne Kościołów Radomskich, seria B: Metryki ślubów, t. 4: Kościót św. Wacława 1701-1795, oprac. M. Jaglarz, G. Fulara, D. Kupisz, Radom 2011.

Księgi Metrykalne Kościołów Radomskich, seria B: Metryki ślubów, t. 5: Kościół św. Jana Chrzciciela 1711-1795, oprac. D. Kupisz, G. Fulara, Radom 2010.

Księgi Metrykalne Kościołów Radomskich, seria C: Metryki zmartych, t. 1: Kościót św. Jana Chrzciciela 1748-1795, oprac. D. Kupisz, Radom 2013.

Niesiecki K., Herbarz Polski, t. 8, wyd. J.N. Bobrowicz, Lipsk 1841.

Nowy Kalendarzyk Polityczny na rok 1825, Warszawa [1824].

Ostrowski T., Prawo cywilne Narodu Polskiego z statutów i konstytucyi koronnych i litewskich zebrane: rezolucyami Rady Nieustaiacey obiaśnione: dodatkami, z praw kanonicznego, magdeburskiego, i chetmińskiego pomnożone: a porzadkiem praw rzymskich ułożone, t. 1, Warszawa 1787.

„Regestr diecezjów” Franciszka Czaykowskiego, czyli właściciele ziemscy w Koronie w 1783 r., wyd. S. Górzyński, Warszawa 2009.

Szlachta wylegitymowana w Królestwie Polskim w latach 1836-1861, oprac. E. Sęczys, Warszawa 2007.

Testamenty chłopów polskich od drugiej połowy XVI do XVIII wieku, oprac. J. Łosowski, Lublin 2016. 
Testamenty szlacheckie z ksiag grodzkich wielkopolskich z lat 1681-1700, oprac. P. Klint, Wrocław 2015.

Testamenty szlachty krakowskiej XVII-XVIII w. Wybór tekstów źródłowych z lat 1650-1799, oprac. A. Falniowska-Gradowska, Kraków 1997.

Testamenty szlachty Prus Królewskich z XVII wieku, oprac. J. Kowalkowski, W. Nowosad, Warszawa 2013.

Testamenty szlachty Prus Królewskich z XVIII wieku, oprac. W. Now os ad, J. Kowalkowski, Warszawa 2016.

Volumina Legum, t. 3-7, wyd. J. Ohryzko, Petersburg 1859-1860.

Źródła i materiały do dziejów szlachty województwa sandomierskiego w XVI-XVIII wieku, t. 3: Akty podziałów dóbr ziemskich szlachty sandomierskiej z XVII wieku, oprac. J. Pielas, Kielce 2014.

\section{Opracowania}

Bar M., Der Adel und der adlige Grundbesitz in Polnisch-Preussen zur Zeit der preussichen Besitzergreifung, Leipzig 1911.

Boniecki A., Herbarz Polski, t. 3-10, Warszawa 1900-1907.

Czapliński W., Długosz J., Życie codzienne magnaterii polskiej w XVII wieku, Warszawa 1982.

Drzewiecki B., Szlachta województwa chetmińskiego w latach 1454-1772, Warszawa 2014.

Instrukcja wydawnicza dla źródet historycznych od XVI do połowy XIX w., red. K. Lepszy, Wrocław 1953.

Jop R., Środowisko urzędnicze kancelarii grodzkich w Chetmie, Lublinie i Krasnymstawie w drugiej połowie XVII wieku, Lublin 2003.

Kalinowski W., Zabudowa rynku radomskiego na przełomie XVIII i XIX wieku, „Biuletyn Kwartalny Radomskiego Towarzystwa Naukowego" (Radom) 1969, t. 6, z. 4, s. 51-79.

Katalogi testamentów mieszkańców miast z terenów Korony i Wielkiego Księstwa Litewskiego do 1795 roku, red. U. Augustyniak, t. 1-7, Warszawa 2017.

Kobierecki M., Walewscy herbu Kolumna w XVII-XVIII wieku. Genealogia. Majętności. Działalność publiczna, Łódź 2008.

Kosińska U., Swidziński Michał h. Półkozic (1736-1788) [w:] Polski Stownik Biograficzny, t. 51, Warszawa-Kraków 2017, s. 289-292.

Kozdrach M., Radom jako miejsce obrad sejmików i lokalnych zjazdów szlacheckich w drugiej połowie XVIII w., „Przegląd Nauk Historycznych” (Łódź), R. 18, 2019, nr 1 (w druku).

Kozdrach M., Urzędnicy grodzcy $i$ personel kancelaryjny radomskiego grodu $w$ latach 1764-1795. Spis, „Studia Mazowieckie” (Pułtusk-Ciechanów), R. 13 (26), 2018, nr 4 (w druku).

Kuklo C., Demografia Rzeczypospolitej przedrozbiorowej, Warszawa 2009.

Kupisz D., Czasy Rzeczypospolitej szlacheckiej (XVI-XVIII wiek) [w:] D. Kupisz, Z. Lechowicz, S. Piątkowski, Dzieje Klwowa i parafii klwowskiej do roku 1918, Radom 2015, s. 39-214.

Kupisz D., Czasy Rzeczypospolitej szlacheckiej (XVI-XVIII wiek) [w:] Powiat radomski. Od średniowiecza do współczesności, red. S. Piątk ow ski, Radom 2009, s. 21-42.

Kupisz D., Dzieje parafii św. Jana Chrzciciela w Radomiu w XIV-XVIII wieku [w:] Kościót św. Jana Chrzciciela w Radomiu. Architektura. Ludzie. Wydarzenia, red. D. Kupisz, Radom 2010, s. 13-60.

Kupisz D., Konfederaci barscy i Kazimierz Pułaski w regionie radomskim [w:] Kazimierz Pułaski i jego czasy w historii, literaturze, kulturze. W 270. rocznice urodzin, red. D. Kupisz, A. Pytlak, Radom-Warka 2016, s. 9-20. 
Kupisz D., Urzędnicy grodzcy radomscy w XVI-XVIII wieku. Stan badań i postulaty badawcze, „Biuletyn Kwartalny Radomskiego Towarzystwa Naukowego” (Radom) 2006, t. 40 , z. 1-4, s. 7-24.

Kupisz D., Kozdrach M., Kochanowscy w XV-XVIII wieku, Warszawa 2018.

Ło sow ski J., Kancelaria grodzka chetmska od XV do XVIII wieku. Studium o urzędzie, dokumentacji, jej formach i roli w życiu społeczeństwa staropolskiego, Lublin 2004.

Łupiński J., Seminarium duchowne w Tykocinie w latach 1769-1863, Łódź 2011.

Mikulski K., Podwójna obsada urzędów ziemskich, urzędy „,tytularne”/,nielegalne” w Rzeczypospolitej w XVII-XVIII w. - kilka uwag wstępnych, „Zapiski Historyczne” (Toruń) 2017 , t. 82, z. 2, s. 71 [258]-83 [269].

Penkała A., Panieńskie ochędóstwo. Kwestie posagowe $i$ wienne w matżeństwach szlachty województwa krakowskiego w czasach saskich, Kraków 2016.

Pielas J., Kariery urzędnicze $i$ pozycja społeczno-majątkowa podkomorzych ziemskich w Małopolsce $w$ XVI-XVII wieku na tle porównawczym, „Klio. Czasopismo poświęcone dziejom Polski i powszechnym" (Toruń) 2015, t. 32, s. 31-57.

Pielas J., Podziały majatkowe szlachty koronnej w XVII wieku, Kielce 2013.

Rolnik D., Portret szlachty czasów stanisławowskich, epoki kryzysu, odrodzenia i upadku Rzeczypospolitej w pamiętnikach polskich, Katowice 2009.

Sozański A., Imienne spisy osób duchownych, świeckich i wojskowych, które w pierwszych ośmiu latach panowania króla Stanisława Poniatowskiego od 1764-1772 r. w rzadzie lub przy administracyi Rzeczypospolitej udziat braty, Kraków 1866.

Suchojad H., Metodologiczne i praktyczne uwarunkowania edycji testamentów - kilka uwag na kanwie publikacji „, Cui contingit nasci...”, „,Kwartalnik Historii Kultury Materialnej" (Warszawa), R. 63, 2015, z. 4, s. 603-609.

Szczepaniak J., Duchowieństwo diecezji krakowskiej w XVIII wieku. Studium prozopograficzne, Kraków 2010.

Urban W., Podwójne obsadzanie urzędów w staropolskim województwie lubelskim, „Przegląd Historyczny" (Warszawa) 1986, t. 77, z. 1, s. 61-69.

Uruski S., Rodzina. Herbarz szlachty polskiej, t. 2-15, Warszawa 1905-1931.

Urzędnicy Prus Królewskich XV-XVIII wieku. Spisy, oprac. K. Mikulski, Wrocław-Warszawa-Kraków 1990.

Urzędnicy województwa sandomierskiego XVI-XVIII wieku. Spisy, oprac. K. Chłapowski, A. Falniowska-Gradowska, Kórnik 1993.

Wiśniewski J., Dekanat konecki, Radom 1913.

Wolff A., Akta partykularne przedrozbiorowe Archiwum Głównego 1381-1835 [w:] Straty archiwów i bibliotek warszawskich $w$ zakresie rękopiśmiennych źródel historycznych, t. 1: Archiwum Główne Akt Dawnych, red. A. Stebelski, Warszawa 1957, s. 175-221.

Wróbel W., Opieka patronacka rodu Zaleskich h. Chomąto nad kościołem parafialnym w Turośni w XVIII w. [w:] Parafia w Turośni Kościelnej 1515-2015. Ku chwale Trójcy Przenajświętszej, red. A. Szot, M. Wróbe1, Białystok-Turośń Kościelna 2015, s. 53-70.

Zielińska T., Szlacheccy właściciele nieruchomości w miastach XVIII w., Warszawa-Łódź 1987.

\section{Materiały internetowe}

Słownik miejscowości i elity wiejskiej zachodniej Małopolski w latach 1772-1815, oprac. Ł. Jewuła, T. Kargol, K. Ślusarek, Kraków 2015 (cz. 1: Miejscowości zachodniej Małopolski), URL: http://www.gospodarka-galicji.pl/slownik-miejscowosci/ (dostęp: 15.05.2019). 